\title{
A scientific note on the lactic acid bacterial flora in honeybees in the USA - A comparison with bees from Sweden*
}

\author{
Alejandra VÁsqueZ ${ }^{1}$, Tobias C. OlOFSSON ${ }^{1}$, Diana SAMMATARO ${ }^{2}$ \\ ${ }^{1}$ Microbiology Laboratory at Campus Helsingborg, Department of Cell and Organism Biology, \\ Lund University Campus Helsingborg, Rönnowsgatan 6, PO Box SE-25108 Helsingborg, Sweden \\ ${ }^{2}$ USDA-ARS Carl Hayden Honey Bee Research Centre, Department of Entomology, University of Arizona, 2000 East \\ Allen Road, Tucson, AZ 85719, USA
}

Received 3 June 2008 - Revised 2 September 2008 - Accepted 2 September 2008

\section{Lactobacillus / Bifidobacterium / Apis mellifera / 16S rRNA genotyping / coevolution}

Recently, it was discovered by Olofsson and Vásquez (2008) that a novel flora composed of lactic acid bacteria (LAB) of the genera Lactobacillus and Bifidobacterium (Fig. 1), exists in the honey stomach of the honeybee Apis mellifera. The ten different flora members varied numerically with the sources of nectar and the presence of other bacterial genera within the honeybee. Closely related phylotypes of some of the lactic acid bacteria have been encountered before in previous work (Scardovi and Trovatelli, 1969; Jeyaprakash et al., 2003; Babendreier et al., 2007) but only in the intestines of honeybees. It appeared that honeybees and the novel LAB flora evolved in mutual dependence on one another, the LAB obtaining a niche in which nutrients were available, the honeybees and their honey in turn being protected by the LAB from harmful microorganisms. In addition, four novel bacterial phylotypes belonging to the family Pasteurellaceae, were discovered (Fig. 1). In other studies, (Jeyaprakash et al., 2003; Babendreier et al., 2007) clones with high sequence similarities have been found (Fig. 1), but again only in the intestines of honeybees.

By comparison, honey stomachs of honeybees (Apis mellifera and A. m. scutellata) collected in the USA were sampled. During spring, honeybees were foraging on flowers that were in bloom (see Tab. I)

Corresponding author: T.C. Olofsson,

Tobias.Olofsson@cob.lu.se

* Manuscript editor: Klaus Hartfelder around the Carl Hayden Honey Bee Lab (Tucson, AZ) which has over 50 colonies of bees on location. Thirty bees that were actively working flowers were collected from each flower type. Between ten and 20 honey stomachs filled with nectar were removed, placed in an Eppendorf tube with $100 \mu$ L physiological saline kept on ice and refrigerated until express shipped with cold packs to Sweden for bacterial analyzes. In Sweden, a total of 45 cultivated isolates were identified using the 16S rRNA gene sequencing technique (methods of Olofsson and Vásquez, 2008).

The results showed that the Swedish bacterial phylotypes, representing all the groups of Lactobacillus and Bifidobacterium, were found in the honey stomachs of American bees (Fig. 1). In addition, a novel Lactobacillus phylotype $3 \mathrm{~d}$ was isolated. This phylotype is possibly a novel species belonging to the Lactobacillus genus. The 16S rRNA gene sequence of $830 \mathrm{bp}$ resembled the type strain of Lactobacillus helveticus DSM $20075^{\mathrm{T}}$ by $92.3 \%$, which is below the threshold level generally used to define a species (95-97\%) (Ludwig et al., 1998).

Babendreier et al. (2007) isolated a clone with high sequence similarity to this phylotype but from the intestines of honeybees (Fig. 1). One of the American honey stomach isolates (B4) was identical in sequence to the Swedish Bifidobacterium phylotype $\operatorname{Trm} 9$ (isolated only from the intestine), which suggests a honey stomach origin.

Olofsson and Vásquez (2008) suggested that the Swedish Lactobacillus kunkeei phylotype Fhon2 


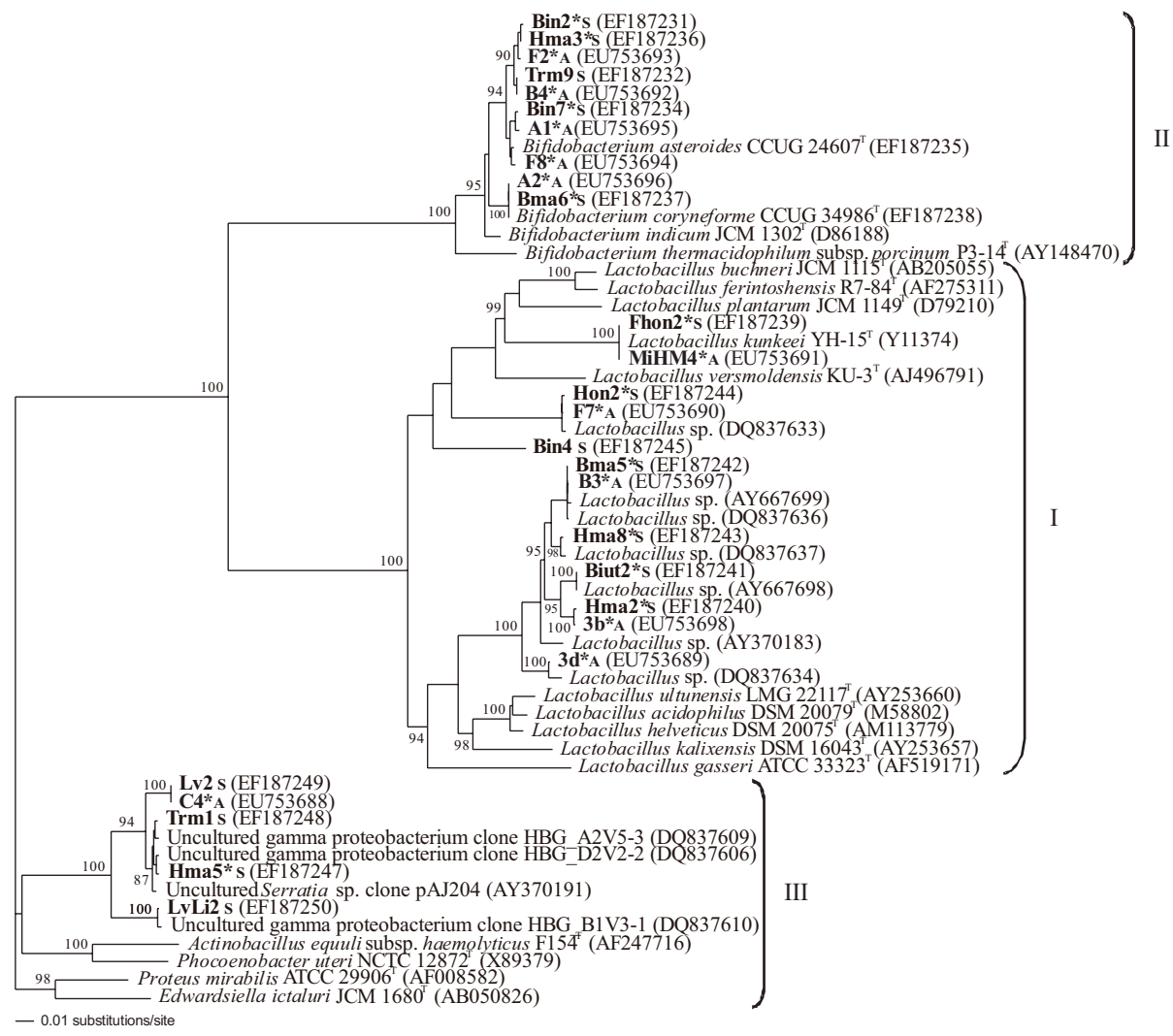

Figure 1. A phylogenetic tree based on a distance matrix analysis of 715 positions in the 16S rRNA gene. Closely related type strains and reference strains are indicated in parenthesis, together with accession numbers from GeneBank. Cluster I displays the Lactobacillus group, cluster II the Bifidobacterium group, and cluster III the Pasteurellaceae group, which served as the out-group. The phylotypes characterised in the study are in bold print and derived from isolates, the accession numbers being included. Honey stomach phylotypes are marked *, Swedish isolates ${ }^{\mathrm{S}}$ and American isolates ${ }^{\mathrm{A}}$. Bar: 0.01 substitutions per nucleotide position. The bacterial 16S rRNA gene sequences were deposited in GenBank using the accession numbers EU753688-EU753698.

dominate the LAB flora and in the American samples it was again shown to dominate (phylotype MiHm4, Fig. 1). The numbers and members of the LAB flora detectable in the Swedish study were low during early spring when the bees began collecting pollen and nectar after the winter. In the first samplings of the American bees, in the early spring, when the bees were foraging on rosemary flowers (Tab. I), LAB flora were again very low. In both studies the LAB increased when the foraging activity increased.

Furthermore, one of the phylotypes (Lv2) belonging to the Pasteurellaceae family, obtained from Swedish honeybee larvae, was discovered in the honey stomach of American bees (C4) (Fig. 1). Together with the Swedish phylotype Hma5 two different phylotypes belonging to the Pasteurellaceae family have now been obtained from the honey stomach. Pasteurellaceae phylotypes have now been detected in honeybees from Sweden, Italy, USA and Switzerland (Fig. 1) indicating that they could be bee specific.

The importance of this discovery will lead to a better understanding of the relationship of beneficial bacteria that co-evolved with honey bees and their continuing health. 
Table I. Bacterial phylotypes, closely related to the Swedish phylotypes, isolated from American honeybee honey stomachs when bees were foraging on the flowers rosemary (Rosmarinus officinalis), wild orange rootstock (Citrus spp.), grapefruit (Citrus paradisi Red var.) and kumquat (Fortunella spp.). Numbers of isolates found, closely related to the Swedish phylotypes by the 16S rRNA gene, are given. Unique American phylotype*.

\begin{tabular}{lcccc}
\hline Phylotype & Rosemary & Bitter orange & Grapefruit & Kumquat \\
\hline Fhon2 & 2 & 2 & 7 & 6 \\
Hon2 & 3 & 3 & \\
Bma5 & & 1 & 1 & \\
Hma2 & & 1 & 6 & 1 \\
3d* & 1 & 2 & \\
Bin7 & & 2 & 1 \\
Hma3 & 1 & 1 & \\
Trm9 & & & 1 \\
Bma6 & & 2 & \\
Lv2 & & & \\
\hline
\end{tabular}

\section{ACKNOWLEDGEMENTS}

This study was financed by Gyllenstiernska Krapperupstiftelsen, Ekhagastiftelsen and Sparbankstiftelsen Skåne. We are grateful for the help of the beekeeper Tage Kimblad, late ass. Prof. Sten Ståhl and others for their knowledge and experience, and for their comments and reflections on our work.

Note scientifique sur la flore des bactéries d'acide lactique chez les abeilles domestiques aux États-Unis - Comparaison avec les abeilles de Suède.

Eine wissenschaftliche Notiz zur Milchsäurebakterienflora in Honigbienen aus den USA - Ein Vergleich mit Bienen aus Schweden.

\section{REFERENCES}

Babendreier D., Joller D., Romeis J., Bigler F., Widmer F. (2007) Bacterial community structures in honeybee intestines and their response to two insecticidal proteins, FEMS Microbiol. Ecol. 59, 600-610.

Jeyaprakash A., Hoy M.A., Allsopp M.H. (2003) Bacterial diversity in worker adults of Apis mellifera capensis and Apis mellifera scutellata (Insecta: Hymenoptera) assessed using 16S rRNA sequences, J. Invertebr. Pathol. $84,96-103$

Ludwig W., Strunk O., Klugbauer S., Klugbauer N., Weizenegger M., Neumaier J., Bachleitner M., Schleifer K.H. (1998) Bacterial phylogeny based on comparative sequence analysis, Electrophoresis 19, 554-568.

Olofsson T.C., Vásquez A. (2008) Detection and identification of a novel lactic acid bacterial flora within the honey stomach of the honeybee Apis mellifera, Curr. Microbiol. 57, 356-363.

Scardovi V., Trovatelli L.D. (1969) New species of bifid bacteria from Apis mellifica L. and Apis indica F. A contribution to the taxonomy and biochemistry of the genus Bifidobacterium, Zentralbl. Bakteriol. Parasitenkd. Infektionskr. Hyg. 123, 64-88. 